\title{
Estimation and Ranking of the Photovoltaic Energy Potential for Local Government Areas in Akwa Ibom State, Nigeria
}

\author{
Abasi-obot Iniobong Edifon ${ }^{1}$, Nkan Imo Edwin ${ }^{1}$, Inyang Aniekan Ben ${ }^{2}$ \\ ${ }^{1}$ Department of Electrical/Electronic Engineering, Akwa Ibom State University, Ikot Akpaden, Mkpat Enin, Nigeria \\ ${ }^{2}$ Department of Electrical/Electronic Engineering, Akwa Ibom State Polytechnic, Ikot Osurua, Ikot Ekpene, Nigeria
}

Email address:

iniobongetokebe61@yahoo.com (Abasi-obot I. E.)

\section{To cite this article:}

Abasi-obot Iniobong Edifon, Nkan Imo Edwin, Inyang Aniekan Ben. Estimation and Ranking of the Photovoltaic Energy Potential for Local Government Areas in Akwa Ibom State, Nigeria. Science Journal of Energy Engineering. Vol. 4, No. 6, 2016, pp. 68-77. doi: 10.11648/j.sjee.20160406.14

Received: October 25, 2016; Accepted: November 17, 2016; Published: January 13, 2017

\begin{abstract}
In this paper, a comparative assessment and ranking of the solar photovoltaic (PV) generation potential and unit cost of energy in ten Local Government Areas (LGAs) in Akwa Ibom State (AKS), Nigeria is presented. The meteorological data used in this study was obtained from the National Aeronautics and Space Administration Surface meteorology and Solar Energy (NASA SSE) website. Photovoltaic System (PVSyst.) simulation software, (Version 5.06) was used for the simulation and determination of the PV energy generation potential and unit cost of energy in each of the LGAs considered. The unit cost of energy in Naira/kWh and available energy per year (in $\mathrm{kWh}$ ) are the two major parameters used to rank the LGAs from the top to bottom. A mathematical model relating the unit cost of energy and available energy in AKS is also developed. From the simulation results, Uyo LGA had the highest yearly energy output of $12422 \mathrm{kWh}$ and lowest unit cost of energy of 104 Naira/kWh, while Uruan LGA had the lowest yearly energy output of $10591 \mathrm{kWh}$ and highest unit cost of energy of 114 Naira/kWh. The results from this research are relevant for facilitating investment and adoption of photovoltaic power systems in AKS and to make realistic economic projections.
\end{abstract}

Keywords: Renewable Energy, Solar Radiation, Unit Cost of Energy, Photovoltaic, Energy Potential, Optimal Tilt Angle

\section{Introduction}

Renewable energy sources are increasingly becoming significant owing to huge demand for energy and the hazardous effects of fossil fuel $[1,2,3]$. The main advantage of renewable energy sources is that, it is pollution free and this preserves the ecological cycle of the global bio-systems $[1,2,4,5]$. Also, the fossil fuel-based energy sources are not renewable. While non- renewable sources of energy are harmful to the environment, inadequate and are in short supply, renewable energy will never run out. Accordingly, the depletion of fossil fuel resources on a worldwide basis has necessitated urgent search for alternative energy sources to meet the present day energy demands. Equally, the urgent need to promote alternative and renewable sources of energy across the globe and especially in Nigeria with perennial power generation shortage cannot be over emphasized. Thus, alternative and renewable energy approach is inevitable, given the fact that the biomass based fuels are increasingly becoming environmentally harmful, and this affects the ecological system. The solar energy resource is therefore one of the best energy alternatives and that is why it has become the focus of this paper [6,7].

Without doubt, the demand for solar electric power systems has grown steadily over the last few decades. Interestingly, AKS has enormous solar potential but the use of solar power is very insignificant when compared to the use of fossil fuel-based power supply. One reason for this is insufficient knowledge of the solar potential of the state and the cost implication of such systems. As such, the focus of this paper is on the techno-economic analysis and ranking of the PV energy potential of LGAs in AKS. 


\section{Methodology}

The work entailed in this paper includes comparative assessment of the PV electric power generation potential and unit cost of electricity at selected LGAs in AKS. Notably, the energy conversion efficiency of PV modules depends on a number of influences among which include: the temperature of the PV module, which in turn depends on the temperature of the surrounding air, on the light intensity and on the local wind speed. All these effects cause the module efficiency to deviate from the efficiency measured under standard test conditions (stc), which defines the rated or nominal power of a given PV module. The energy production of a given PV module would also vary, due to other none intrinsic factors relating to the details of installation (such as the inclination angle and possible shadows) to the total amount of solar radiation at the site of installation, or the probability of dust or snow deposition.

Consequently, in this paper, PVSyst. software is used to

$$
\frac{G(\beta)}{G\left(\beta_{o p t}\right)}=1+4.46 \times\left(10^{-4}\right)\left(\beta-\beta_{o p t}\right)-1.19 \times\left(10^{-4}\right)\left(\beta-\beta_{o p t}\right)^{2}
$$

Where: $\mathrm{G}(\beta)$ in $\mathrm{Wh} / \mathrm{m} 2$ is the daily global irradiation at an angle $\beta^{\circ}$ and $\beta_{\text {opt }}$ the optimal inclination, $G\left(\beta_{\text {opt }}\right)$ in $\mathrm{Wh} / \mathrm{m}^{2}$ is the global irradiation at an the optimal angle $\beta_{\text {opt }}$. $\beta$ and $\beta_{\text {opt }}$ are in degrees. The optimal inclination $\left(\beta_{\text {opt }}\right)$ can be calculated with $(8,9,10]$ :

$$
\beta_{\text {opt }}=3.7+0.69|\emptyset|
$$

where: $\emptyset$ is the local latitude in degrees.

When global irradiation on horizontal plane is given $\left(\beta=0^{\circ}\right)$ and the optimal tilt angle is also given, then the transposition factor is obtained from equation 3 ;

$$
\begin{gathered}
\text { Transposition Factor }=\frac{G\left(\beta_{o p t}\right)}{G(\beta)} \\
\text { where }\left(\beta=0^{\circ}\right)
\end{gathered}
$$

\subsection{Determination of Effective Rooftop Area for Photovoltaic Panel Installation}

In this paper, the rooftop PV electric power generation potential of a facility was considered. The facility considered was Zinox-building located at the main campus of the University of Uyo, Uyo. The total rooftop area was calculated based on empirical measurement of the dimensions of the roof of the buildings. There are many factors which influence the fraction of available roof area for PV power installations. The factors include:

i. the orientation of pitched roofs;

ii. the installation and racking of the PV panels;

iii. the use of roof space for other applications, such as ventilation, heating/air conditioning, dormers or chimneys; and

iv. shading from other parts of the roof or from neighbouring buildings and trees;

To account for these factors, a reduction in the overall conduct simulated analysis of the PV electric power generation potential of the selected LGAs in AKS. Thereafter, the LGAs are ranked according to their solar energy potential.

\subsection{Solar Radiation, Ambient Temperature and Wind Speed Data}

The data were obtained from the NASA Langley Research Center Atmospheric Science Data Center Surface meteorological and Solar Energy (SSE) web portal supported by the NASA LaRC power project. The data consist of 22-year NASA SSE monthly average global radiation horizontal plane,

The global solar radiation horizontal plane is the sum of both the direct and diffuse radiation components as measured incident on a flat horizontal plane. When global irradiation at an angle $\beta^{\circ}$ is given, then the irradiation on the inclined plane is given as $[8,9]$;

suitable rooftop area was applied. The reduction process for this analysis was determined as follows;

Let $r_{\text {flat }}$ be the proportion of flat rooftops in the set of buildings considered.

Let $r_{\text {peak }}$ be the proportion of pitched rooftops in the set of buildings considered.

Let $\mathrm{f}_{\text {flat }}$ be the reduction factor for flat rooftops. All flat rooftops are assumed to be unaffected by their rooftop orientation. More simply, because they have a flat rooftop, it does not matter which direction the building is facing to receive optimal sun exposure. As such,

$$
f_{\text {flat }}=1 \text { or } 100 \% \text {. }
$$

Let $\mathrm{f}_{\text {peak }}$ be the reduction factor for pitched rooftops. For pitched rooftops however, half of all peaked rooftops are assumed to have suitable northern exposure. This assumption meant that;

$$
f_{\text {peak }}=0.5 \text { or } 50 \% \text {. }
$$

AKS is located in the Southern part of Nigeria. In this case, the PV-appropriate roof space orientation is that which faces North. Also, the set of roofs considered in this paper possess pitched roofs. Let $f_{o}$ be the fraction of properly oriented roof area, [11, 12];

$$
f_{o}=\left(f_{\text {flat }} \times r_{\text {flat }}\right)+\left(f_{\text {peak }} \times r_{\text {peak }}\right)
$$

For instance, if $\mathrm{f}_{\text {flat }}=100 \% ; \mathrm{r}_{\text {flat }}=25 \% ; \mathrm{f}_{\text {peak }}=$ $50 \%$ andr $_{\text {peak }}=95$, then $f_{o}=(1 \times 0.25)+(0.5 \times 0.95)=$ 0.625

The rooftop area is further reduced by another factor, $\mathrm{f}_{\mathrm{s}}$ which accounts for other unknowns such as shadow from trees, and areas needed for other kinds of installations on the roof, as well as the installations of the solar panels themselves and other barriers to construction. The reduction fractions ambient temperature and wind speed. 
used for this formula are taken directly from available literature [12]. According toWiginton, et al., [11], a fraction of 0.30 formulated by Ghosh and Vale [13] was used and represented as $f_{s}$. Unlike Wiginton, et al., [11], the purpose of this paper was to show a range in estimation from best to worst case scenario. As such, the more liberal estimation of 0.90 from [12] was taken. Each value was multiplied to the result of $\mathrm{f}_{\mathrm{o}}$ in order to find the total roof area available for PV installations. The formula for this estimation is presented below.

$$
A_{\text {pv }}=A_{\text {pvroof }}=A_{\text {roof }} \times f_{o} \times f_{s}
$$

Where:

$\mathrm{A}_{\text {roof }}=$ the total available rooftop area

$A_{\text {pvroof }}=$ the effective rooftop area available for the PV installations

The worst case scenario $\mathrm{f}_{\mathrm{s}}=0.3$ thatis $30 \%$ whereas, the best case scenario,

$\mathrm{f}_{\mathrm{s}}=0.9$ that is $90 \%$.

In this paper, $\mathrm{f}_{\mathrm{o}}=50 \%=0.5$ and $\mathrm{f}_{\mathrm{s}}=90 \%=0.9$

$A_{\text {pv }}=A_{\text {pvroof }}=A_{\text {roof }} \times 0.5 \times 0.9=0.45 A_{\text {roof }}$

The roof area $A_{\text {roof }}=92.4 \mathrm{~m}^{2}$, such that,

$$
A_{p v}=0.45 A_{\text {roof }}=0.45 \times 92.4=41.57 \mathrm{~m}^{2}
$$

\subsection{Determination of the Photovoltaic Electric Power Generation Potential for $A$}

Given Available Rooftop Area

For any given daily load demand $\left(\mathrm{E}_{\mathrm{L}}\right)$ inkWh/day, the PV size in terms of area $\left(A_{p v}\right)$ required to meet the daily load demand is given as:

$$
A_{p v}=\frac{E_{L}}{G_{d} \mathrm{x} \eta_{p v}}
$$

The size of the PV array used in this study can be calculated by using equation 6 .

Where: $E_{L}$ is the daily load demand, $G_{d}$ is solar energy input per day on PV panels in $\mathrm{kW} / \mathrm{m}^{2} /$ day and $\eta_{\mathrm{pv}}$ is the PV efficiency. Conversely, for any given PV size in terms of area $\left(A_{p v}\right)$, the daily energy output $(E)$ of the $P V$ is given as [14];

$$
E=G_{d} \mathrm{x \eta}_{p v} \mathrm{x} A_{p v}
$$

In order to allow for other system losses a safety factor (Sf) is introduced as follows.

$$
E=\left(G_{d} \mathrm{x \eta}_{p v} \mathrm{x} A_{p v}\right) \mathrm{Sf}
$$

The total annual energy output is calculated as [14];

$$
\mathrm{E}=\left(G_{d} \times 365 \times \eta_{p v} \times A_{p v}\right) \mathrm{Sf}
$$

$A_{p v}=41.57 m^{2} \quad, \quad \eta_{p v}=14.5 \% G_{d}=5.887419$ $\mathrm{kWh} / \mathrm{m}^{2} /$ day and $\mathrm{Sf}=1.2$

Thus, using equation $9, \mathrm{E}=15517.264198635 \mathrm{kWh}$ per year.

\section{Results and Discussions}

The results presented in the paper shows the solar energy potential for selected LGAs in AKS.

\subsection{The Co-ordinates of the Local Government Areas in Akwa Ibom State}

In order to assess and estimate the solar energy potential of AKS, ten LGAs in AKS were selected out of the 31 LGAs in AKS. The coordinates of the 10 selected LGAs in AKS, is as given in Table 1.

Table 1. The coordinates of the 10 Local Government Areas in Akwa Ibom State.

\begin{tabular}{llll}
\hline $\mathbf{S} / \mathbf{N}$ & LGA & Latitude $\left(^{\circ}\right)$ & Longitude $\left({ }^{\circ} \mathbf{E}\right)$ \\
\hline 1 & Abak & 5.003394 & 7.774887 \\
2 & Eket & 4.651073 & 7.932042 \\
3 & Ibeno & 4.571247 & 7.982284 \\
4 & Ika & 5.030528 & 7.5513 \\
5 & IkotAbasi & 4.580055 & 7.539742 \\
6 & Ini & 5.327954 & 7.71939 \\
7 & Itu & 5.203613 & 7.968864 \\
8 & Oron & 4.806522, & 8.233081 \\
9 & Uruan & 5.129222 & 7.980461 \\
\hline 10 & Uyo & 5.031486 & 7.910069 \\
\hline
\end{tabular}

\subsection{Solar Radiation Data Representation and Analysis}

The meteorological data for the selected LGAs are downloaded directly into PVSyst. from NASA SSE website. After downloading the 22-years average solar radiation data from NASA website, PVSyst generates the average hourly global irradiance and temperature data with which it performed the simulation of PV systems. The PVSysts-generated hourly solar data of Table 2 and Figure 1 for Uyo are used to present typical average hourly global irradiance on horizontal plane in $\left(\mathrm{W} / \mathrm{m}^{2}\right)$ and on tilted plane in $\left(\mathrm{W} / \mathrm{m}^{2}\right)$ for the month of January.

In addition, PVSyst. also generates the average daily and average monthly solar radiation data. Table 3 and Figure 2 are the average daily global irradiation on horizontal plane and on tilted plane in $\left(\mathrm{kWh} / \mathrm{m}^{2}\right)$ for the month of January in Uyo LGA. Similarly, Table 4 and Figure 3 shows monthly global irradiation on horizontal plane and on tilted plane $\left(\mathrm{kWh} / \mathrm{m}^{2}\right)$ and the monthly transposition factors for Uyo LGA.

According to Table 2 and Figure 1, the hourly global irradiance (in $\mathrm{W} / \mathrm{m}^{2}$ ) is non-zero for the hours of $7 \mathrm{am}$ to $6 \mathrm{pm}$. The peak value of occurred between the hours of 11 am to 12 noon. The peak value for the average hourly global irradiance on horizontal plane is $584.67 \mathrm{~W} / \mathrm{m}^{2}$ whereas, the peak value for the average hourly global irradiance on tilted plane is $615.33 \mathrm{~W} / \mathrm{m}^{2}$. 
Table 2. Average hourly global irradiance on horizontal plane and on tilted plane $\left(\mathrm{W} / \mathrm{m}^{2}\right)$ for the first day in the month of January in Uyo LGA.

\begin{tabular}{llllll}
\hline $\begin{array}{l}\text { Time of the } \\
\text { Day (hours) }\end{array}$ & $\begin{array}{l}\text { Average Hourly Global } \\
\text { Irradiance Horizontal } \\
\text { plane }\left(\mathbf{W} / \mathbf{m}^{2}\right)\end{array}$ & $\begin{array}{l}\text { Average Hourly Global } \\
\text { Irradiance on Tilted plane } \\
\left(\mathbf{W} / \mathbf{m}^{2}\right)\end{array}$ & $\begin{array}{l}\text { Time of the Day } \\
\text { (hours) }\end{array}$ & $\begin{array}{l}\text { Average Hourly Global } \\
\text { Irradiance Horizontal } \\
\text { plane }\left(\mathbf{W} / \mathbf{m}^{2}\right)\end{array}$ & $\begin{array}{l}\text { Average Hourly Global } \\
\text { Irradiance on Tilted } \\
\text { plane }\left(\mathbf{W} / \mathbf{m}^{2}\right)\end{array}$ \\
\hline 0 & 0 & 0 & 12 & 548.33 & 569.33 \\
1 & 0 & 0 & 13 & 459 & 470 \\
2 & 0 & 0 & 14 & 522 & 546 \\
3 & 0 & 0 & 15 & 437 & 460.33 \\
4 & 0 & 0 & 16 & 334.33 & 365 \\
5 & 0 & 0 & 17 & 129 & 142.67 \\
6 & 0 & 0 & 18 & 0 & 0 \\
7 & 120.33 & 135.67 & 19 & 0 & 0 \\
8 & 269.33 & 286 & 20 & 0 & 0 \\
9 & 385.33 & 402 & 21 & 0 & 0 \\
10 & 571.33 & 604.67 & 22 & 0 & 0 \\
11 & 584.67 & 615.33 & 23 & 0 & 0 \\
\hline
\end{tabular}

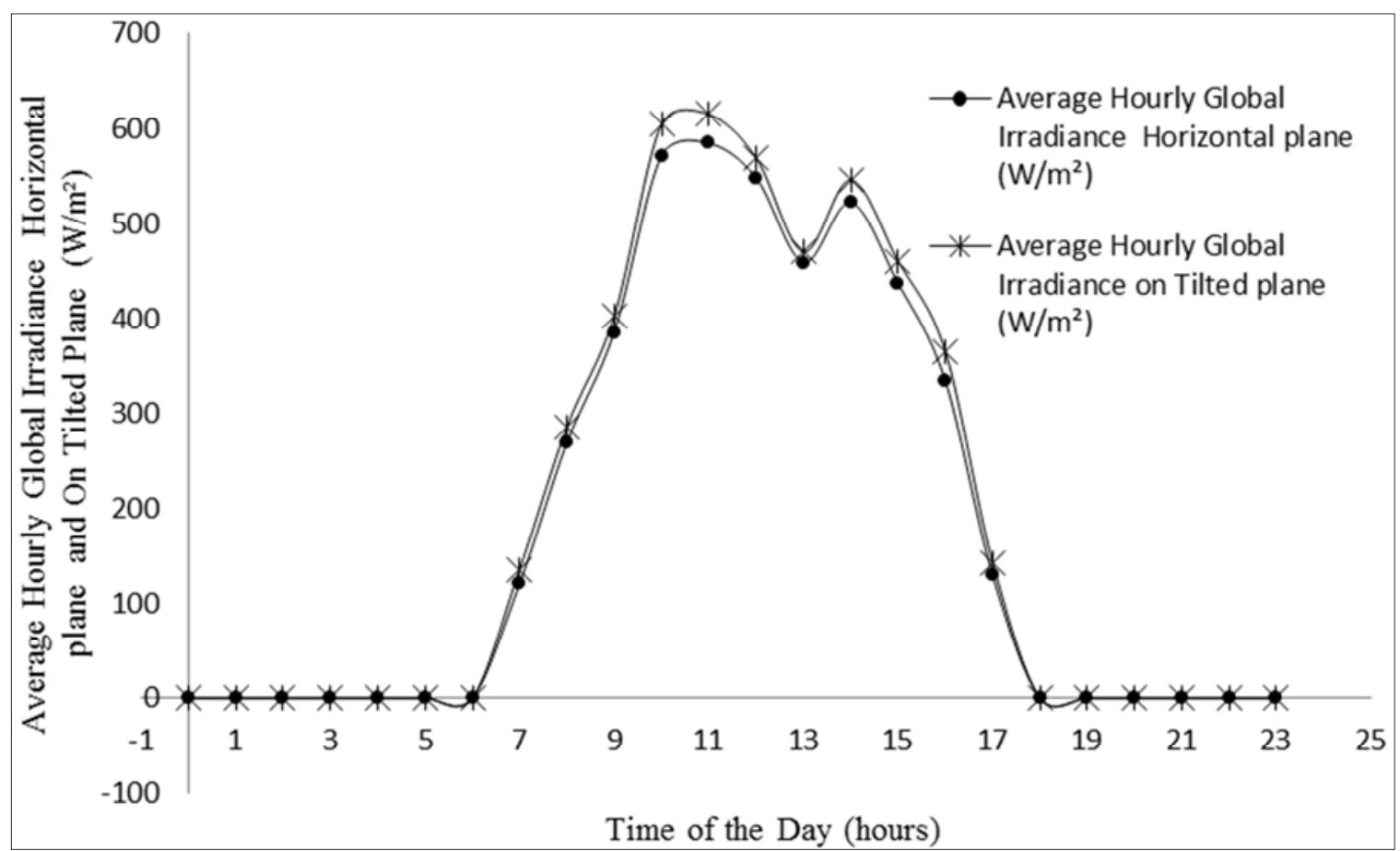

Figure 1. Average hourly global irradiance on horizontal plane and on tilted plane $\left(\mathrm{W} / \mathrm{m}^{2}\right)$ for the 1st day in the month of January in Uyo LGA.

Table 3. Average daily global irradiation on horizontal plane and on tilted plane $\left(\mathrm{kWh} / \mathrm{m}^{2}\right)$ for the month of January in Uyo LGA.

\begin{tabular}{|c|c|c|c|c|c|}
\hline $\begin{array}{l}\text { Days of the } \\
\text { Month }\end{array}$ & $\begin{array}{l}\text { Average Daily Global } \\
\text { Irradiation Horizontal } \\
\text { Plane }\left(\mathbf{K w h} / \mathbf{M}^{2}\right)\end{array}$ & $\begin{array}{l}\text { Average Daily Global } \\
\text { Irradiation On Tilted } \\
\text { Plane }\left(K w h / \mathbf{M}^{2}\right)\end{array}$ & $\begin{array}{l}\text { Days Of The } \\
\text { Month }\end{array}$ & $\begin{array}{l}\text { Average Daily Global } \\
\text { Irradiation Horizontal Plane } \\
\left(\mathbf{K w h} / \mathbf{M}^{2}\right)\end{array}$ & $\begin{array}{l}\text { Average Daily Global } \\
\text { Irradiation On Tilted } \\
\text { Plane }\left(\mathrm{Kwh} / \mathbf{M}^{2}\right)\end{array}$ \\
\hline 1 & 3.215 & 3.273 & 17 & 5.97 & 6.394 \\
\hline 2 & 5.339 & 5.72 & 18 & 5.631 & 5.995 \\
\hline 3 & 4.528 & 4.798 & 19 & 6.012 & 6.446 \\
\hline 4 & 5.881 & 6.325 & 20 & 5.957 & 6.349 \\
\hline 5 & 5.488 & 5.889 & 21 & 4.922 & 5.168 \\
\hline 6 & 5.629 & 6.044 & 22 & 3.115 & 3.147 \\
\hline 7 & 6.686 & 7.236 & 23 & 4.179 & 4.306 \\
\hline 8 & 5.376 & 5.756 & 24 & 6.746 & 7.226 \\
\hline 9 & 6.087 & 6.558 & 25 & 6.203 & 6.603 \\
\hline 10 & 6.2 & 6.707 & 26 & 5.63 & 5.981 \\
\hline 11 & 5.497 & 5.878 & 27 & 4.867 & 5.102 \\
\hline 12 & 6.574 & 7.093 & 28 & 5.823 & 6.144 \\
\hline 13 & 6.065 & 6.524 & 29 & 4.728 & 4.914 \\
\hline 14 & 4.017 & 4.17 & 30 & 5.937 & 6.29 \\
\hline 15 & 6.526 & 7.033 & 31 & 6.295 & 6.669 \\
\hline 16 & 6.303 & 6.772 & Daily Average & 5.529871 & 5.887419 \\
\hline
\end{tabular}




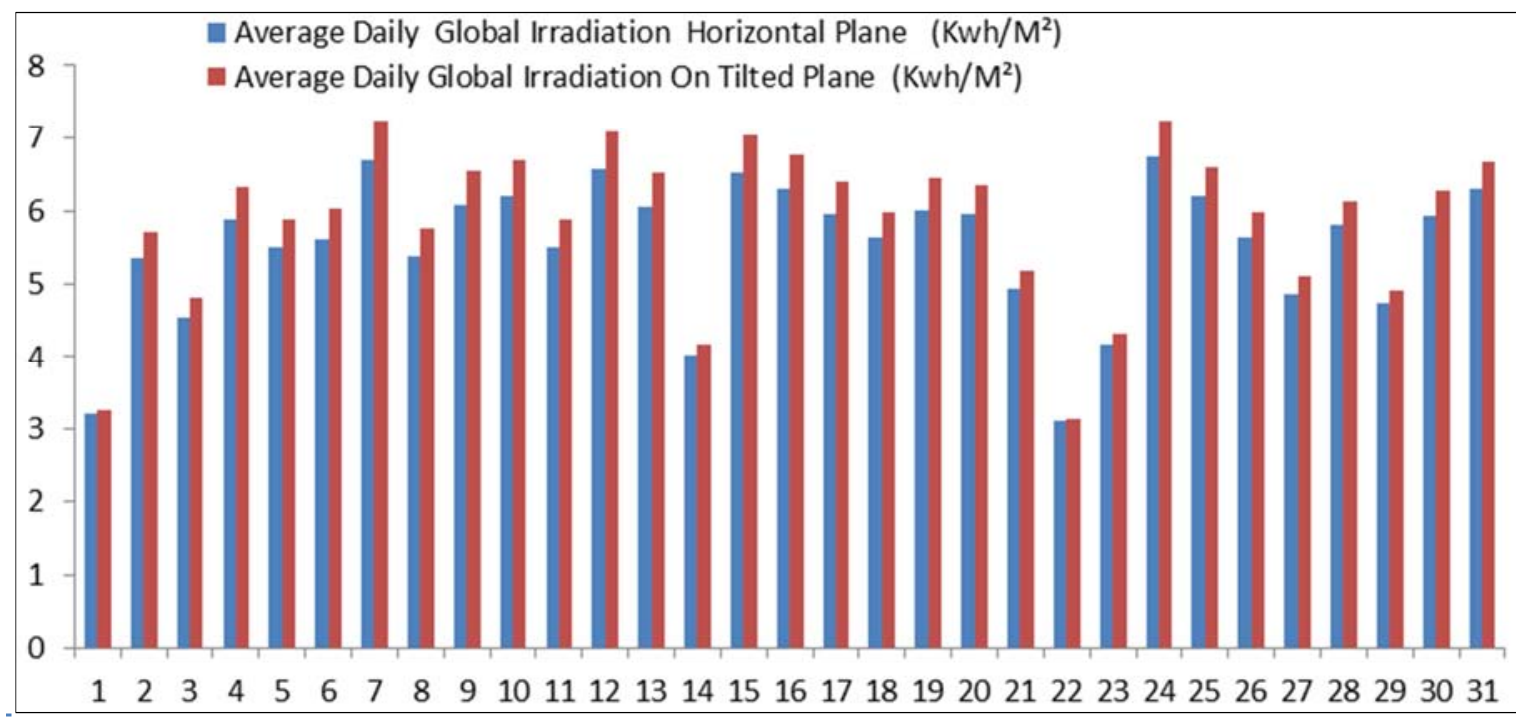

Figure 2. Average daily global irradiation on horizontal plane and on tilted plane $\left(\mathrm{kWh} / \mathrm{m}^{2}\right)$ for the month of January in Uyo LGATable 4 and Figure 3, show the average monthly global irradiation on horizontal plane and on tilted plane in Uyo. According to Table 4 and Figure 3, the yearly average global irradiation on horizontal plane is $1545.8 \mathrm{kWh} / \mathrm{m}$, the yearly average global irradiation on tilted plane is $1553.1 \mathrm{kWh} / \mathrm{m}$, and the yearly average of the transposition factor is 1.01. Essentially, there is about $1 \%$ gain in irradiation by tilting the PV array to the 8 degrees optimal tilt angle.

Generally, in PVSyst. simulation, two seasons are identified in a year, namely; summer (April to September) and winter (October to March). These two seasons are similar to the dry and wet seasons in Nigeria. The PV array optimal tilt angle can be set with respect to the summer and winter on the yearly average. In any case, the summer season has much lower solar potential than the winter as indicated by the data in Table 5 .

Table 4. Monthly global irradiation on horizontal plane and on tilted plane $\left(\mathrm{kWh} / \mathrm{m}^{2}\right)$ and the monthly transposition factors for Uyo LGA.

\begin{tabular}{|c|c|c|c|}
\hline Months & Global Irradiation On Horizontal Plane $\left(\mathrm{kWh} / \mathrm{m}^{2}\right)$ & Global Irradiation On Tilted Plane $\left(\mathrm{kWh} / \mathrm{m}^{2}\right)$ & Transposition Factor \\
\hline August & 116.9 & 114 & 0.98 \\
\hline September & 118.2 & 117.8 & 1.00 \\
\hline July & 119.4 & 114.7 & 0.96 \\
\hline June & 129.3 & 123.2 & 0.95 \\
\hline October & 132.4 & 135.2 & 1.02 \\
\hline November & 145.2 & 152.7 & 1.05 \\
\hline May & 146.3 & 140.9 & 0.96 \\
\hline April & 152.7 & 149.8 & 0.98 \\
\hline February & 156.5 & 162.8 & 1.04 \\
\hline December & 164 & 175.4 & 1.07 \\
\hline March & 164.9 & 166.6 & 1.01 \\
\hline January & 171.4 & 182.5 & 1.06 \\
\hline Yearly Average & 1545.8 & 1553.1 & 1.01 \\
\hline
\end{tabular}

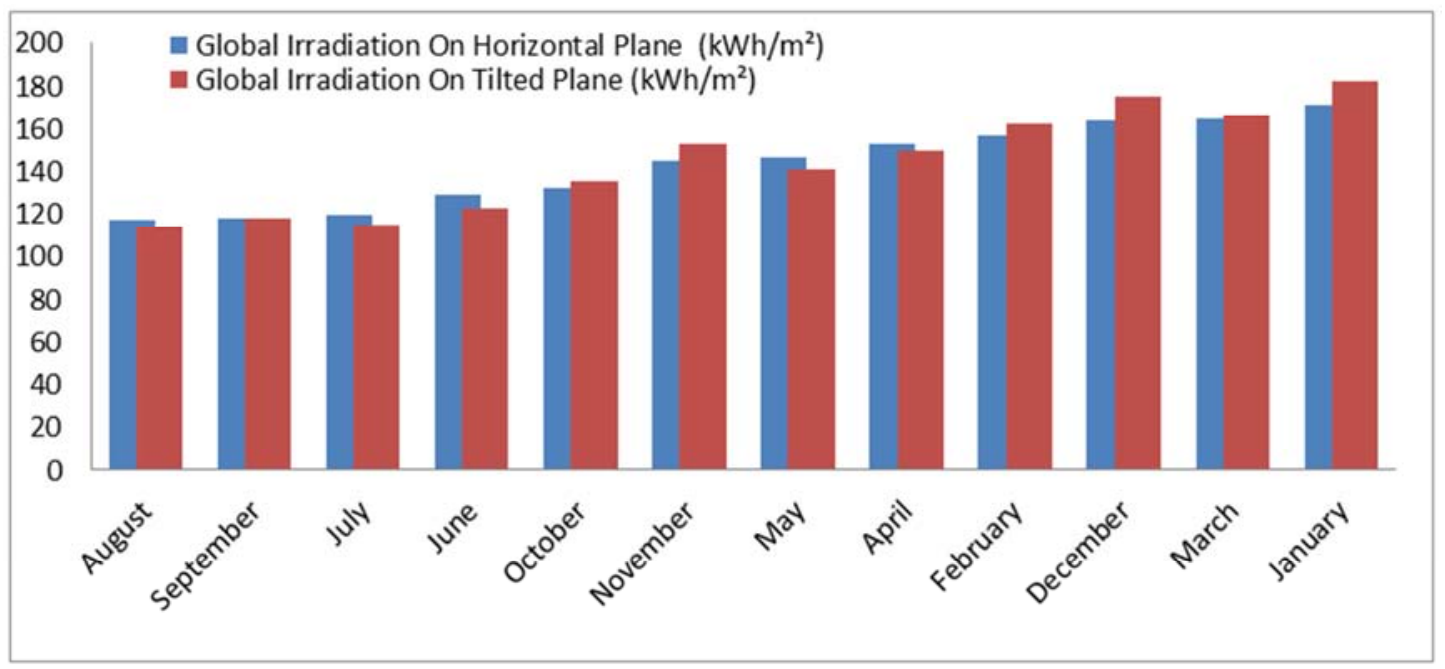

Figure 3. Monthly global irradiation on horizontal plane and on tilted plane $\left(\mathrm{kWh} / \mathrm{m}^{2}\right)$. 
Table 5. Seasonal (summer and winter) solar radiation data for Uyo LGA.

\begin{tabular}{llll}
\hline Solar radiation parameters & summer (April to September) & winter (October to March) & Percentage of winter to summer Parameters \\
\hline $\begin{array}{l}\text { Global Irradiation On } \\
\text { Horizontal Plane }\left(\mathrm{kWh} / \mathrm{m}^{2}\right)\end{array}$ & 782.80 & 934.40 & 19.37 \\
$\begin{array}{l}\text { Global Irradiation On } \\
\text { Tilted Plane }\left(\mathrm{kWh} / \mathrm{m}^{2}\right)\end{array}$ & 760.40 & 975.20 & 28.25 \\
Transposition Factor & 0.97 & 1.04 & 7.34 \\
Ambient Temperature $\left({ }^{\circ} \mathrm{C}\right)$ & 24.72 & 25.12 & 1.62 \\
Wind Velocity $(\mathrm{m} / \mathrm{s})$ & 2.24 & 2.03 & -9.02 \\
Array $($ Cell) Temperature & 37.07 & 39.81 & 7.40 \\
Available Energy $(\mathrm{kWh})$ & 5193.00 & 7228.00 & 39.19 \\
Thermal Loss $(\mathrm{kWh})$ & 555.20 & 916.30 & 65.04 \\
Thermal Loss $(\%)$ of & 10.54 & 12.62 & 19.76 \\
Available Energy & 86.95 & -28.16 \\
Monthly Unit Cost of Energy & 121.04 & 86.95 \\
\hline
\end{tabular}

Tilting the PV array with respect to the summer season gives lower solar potential and higher unit cost for the energy but it ensures that the load demand is satisfied most of the times in the year. Using the yearly average or winter season gives higher solar potential but in this case, the load demand is not satisfied in most cases, especially those summer months with poor solar irradiance values. For this reason, the yearly average is used for the analysis in this paper.

According to Table 6 and Figure 4, the peak value of 1717.2
$\mathrm{kWh} / \mathrm{m}^{2}$ for the average yearly global irradiation on horizontal plane occurred in Uyo, Ika, Itu and Abak whereas, the lowest value of $1535.3 \mathrm{kWh} / \mathrm{m}^{2}$ for the average yearly global irradiation on horizontal plane occurred in Ikot Abasi and Ibeno. Similarly, value of $1737.3 \mathrm{kWh} / \mathrm{m}^{2}$ for the average yearly global irradiation on tilted plane occurred in Itu whereas, the lowest value of $1550.1 \mathrm{kWh} / \mathrm{m}^{2}$ for the average yearly global irradiation on tilted plane occurred in IkotAbasi.

Table 6. Yearly global irradiation on horizontal plane and on tilted plane $\left(\mathrm{kWh} / \mathrm{m}^{2}\right)$ and transposition factor for the $10 \mathrm{LGAs}$ in AKS.

\begin{tabular}{llll}
\hline LGAs & Global Irradiation On Horizontal Plane $\left(\mathbf{k W h} / \mathbf{m}^{2}\right)$ & Global Irradiation On Tilted Plane $\left(\mathbf{k W h} / \mathbf{m}^{2}\right)$ & Transposition Factor \\
\hline IkotAbasi & 1535.3 & 1550.1 & 1.01 \\
Ibeno & 1535.3 & 1550.3 & 1.01 \\
Uruan & 1535.3 & 1553.1 & 1.012 \\
Eket & 1558.4 & 1576.4 & 1.012 \\
Oron & 1558.4 & 1578 & 1.013 \\
Ini & 1650.2 & 1671.6 & 1.013 \\
Uyo & 1717.2 & 1735.6 & 1.011 \\
Ika & 1717.2 & 1735.6 & 1.011 \\
Abak & 1717.2 & 1736.3 & 1.011 \\
Itu & 1717.2 & 1737.3 \\
\hline
\end{tabular}

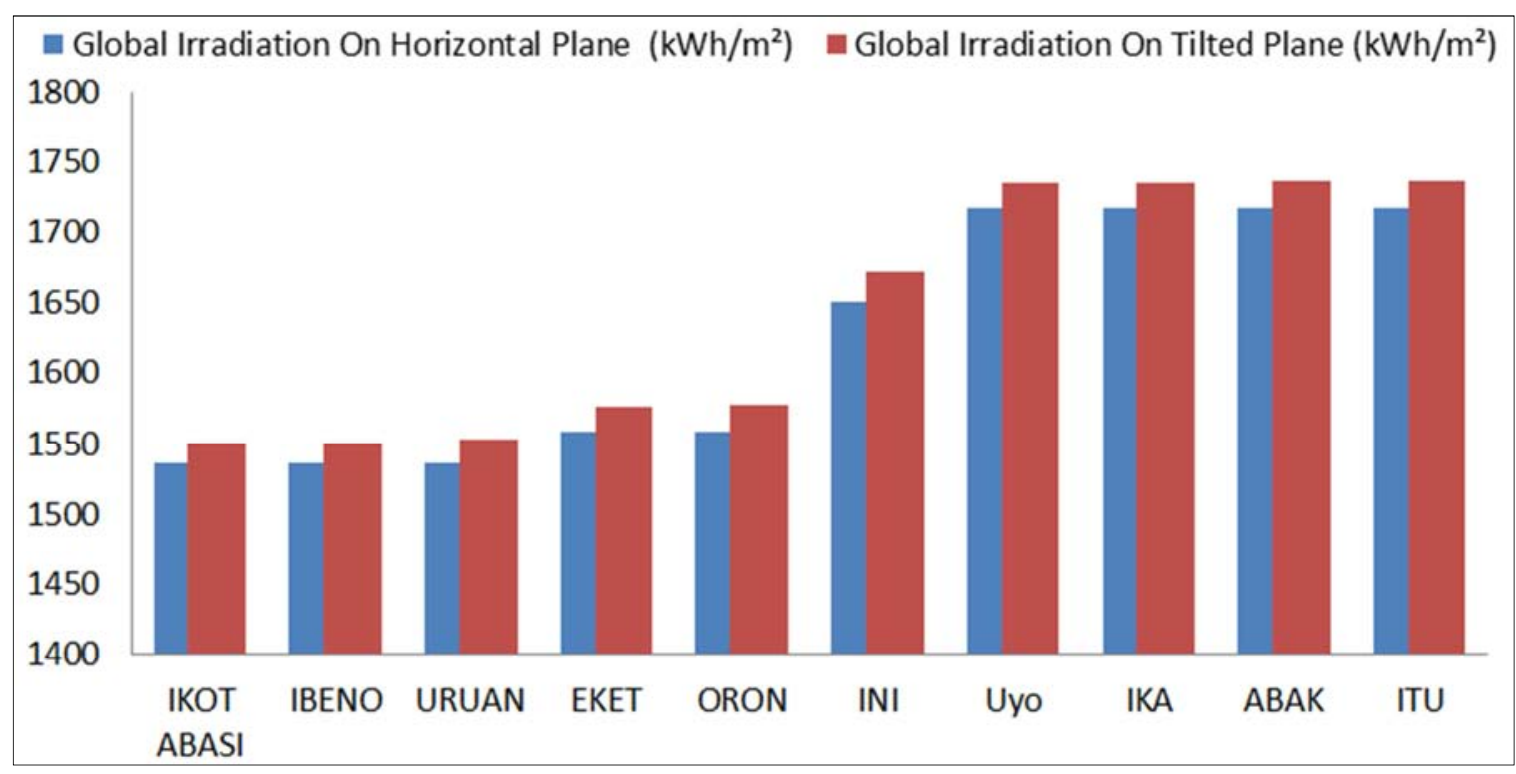

Figure 4. Yearly global irradiation on horizontal plane and on tilted plane $\left(\mathrm{kWh} / \mathrm{m}^{2}\right)$ for the $10 \mathrm{LGAs}$ in AKS.

The rooftop of the Zinox laboratory at the faculty of Engineering University of Uyo main campus was used as a sample facility to determine the solar energy potential of typical rooftop area in Akwa Ibom state. The Zinox laboratory 
has rooftop area $A_{\text {roof }}=92.4 \mathrm{~m}^{2}$, then;

$$
A_{p v}=0.45 A_{\text {roof }}=0.45 \times 92.4=41.57 \mathrm{~m}^{2}
$$

The same effective $\mathrm{PV}$ rooftop area $\mathrm{A}_{\mathrm{pv}}=41.57 \mathrm{~m}^{2}$ is used in the PVSyst to simulate for the solar energy potential in the 10 LGAs considered.

Table 7 and Figure 5, showthe ambient temperature $\left({ }^{\circ} \mathrm{C}\right)$, wind speed $(\mathrm{m} / \mathrm{s})$ and cell temperature $\left({ }^{\circ} \mathrm{C}\right.$ for the 10 LGAs in AKS. According to Table 7 and Figure 5, the peak value of array (cell) temperature (of $40.43^{\circ} \mathrm{C}$ occurred in Ini whereas, the lowest value of array (cell) temperature of $36.5^{\circ} \mathrm{C}$ occurred in Oron. Accordingly, in Table 8 and Figure 6, the peak value of thermal loss of $1606.7 \mathrm{kWh}$ occurred in Ini whereas, the lowest value of thermal loss of $1220.9 \mathrm{~kW} / \mathrm{h}$ occurred in Oron.

According to Table 8 and Figure 6 , the peak value of solar energy generated by the PV array is $12422 \mathrm{~kW} / \mathrm{h}$ and it occurred in Uyo whereas, the lowest value of solar energy generated by the PV array is $10591 \mathrm{~kW} / \mathrm{h}$ and it occurred in Uruan.

Table 7. Ambient Temperature $\left({ }^{\circ} \mathrm{C}\right)$, Wind Speed $(\mathrm{m} / \mathrm{s})$ and Cell Temperature $\left({ }^{\circ} \mathrm{C}\right)$.

\begin{tabular}{llll}
\hline LGAs & Ambient Temperature $\left({ }^{\circ} \mathbf{C}\right)$ & Wind Velocity $(\mathbf{m} / \mathbf{s})$ & Array $(\mathbf{C e l l})$ Temperature $\left({ }^{\circ} \mathbf{C}\right)$ \\
\hline Oron & 24.66 & 2.17 & 36.5 \\
Uyo & 24.91 & 2.13 & 38.28 \\
Abak & 24.91 & 2.13 & 38.28 \\
Itu & 24.91 & 2.13 & 38.33 \\
Eket & 24.66 & 2.77 & 38.4 \\
Ika & 24.91 & 2.13 & 38.46 \\
Ibeno & 25.33 & 2.77 & 39.11 \\
IkotAbasi & 25.33 & 2.77 & 39.11 \\
Uruan & 25.33 & 2.77 & 39.13 \\
Ini & 25.59 & 2.13 & 40.43 \\
\hline
\end{tabular}

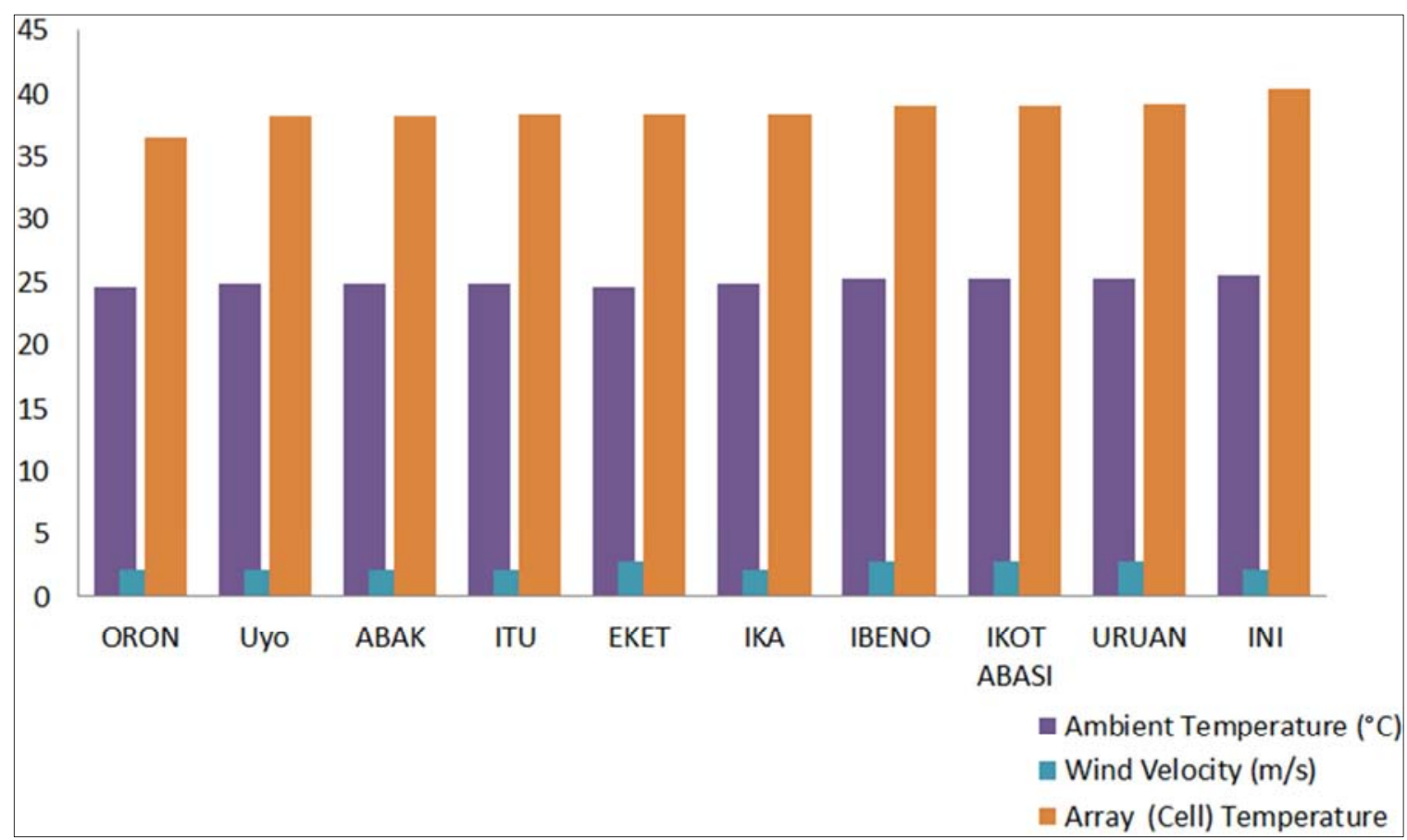

Figure 5. Ambient temperature $\left({ }^{\circ} \mathrm{C}\right)$, wind speed $(\mathrm{m} / \mathrm{s})$ and cell temperature $\left({ }^{\circ} \mathrm{C}\right)$.

Table 8. Available energy $(\mathrm{kW} / \mathrm{h})$, thermal loss $(\mathrm{kW} / \mathrm{h})$ and percentage of thermalloss to the available energy.

\begin{tabular}{llll}
\hline LGAs & Available Energy $(\mathbf{k W} / \mathbf{h})$ & Thermal Loss $(\mathbf{k W} / \mathbf{h})$ & Thermal Loss $(\%)$ of Available Energy \\
\hline Uruan & 10591 & 1356.9 & 12.81182136 \\
Ibeno & 10653 & 1384.4 & 12.99540036 \\
IkotAbasi & 10692 & 1373.7 & 12.84792368 \\
Eket & 10906 & 1375 & 12.60774 \\
Oron & 11066 & 1220.9 & 11.03289355 \\
Ini & 11692 & 1606.7 & 13.74187 \\
Abak & 12256 & 1410.7 & 11.51028 \\
Ika & 12328 & 1479.7 & 12.00275795 \\
Itu & 12418 & 1467.4 & 11.81671767 \\
Uyo & 12422 & 1471.4 & 11.84511351 \\
\hline
\end{tabular}




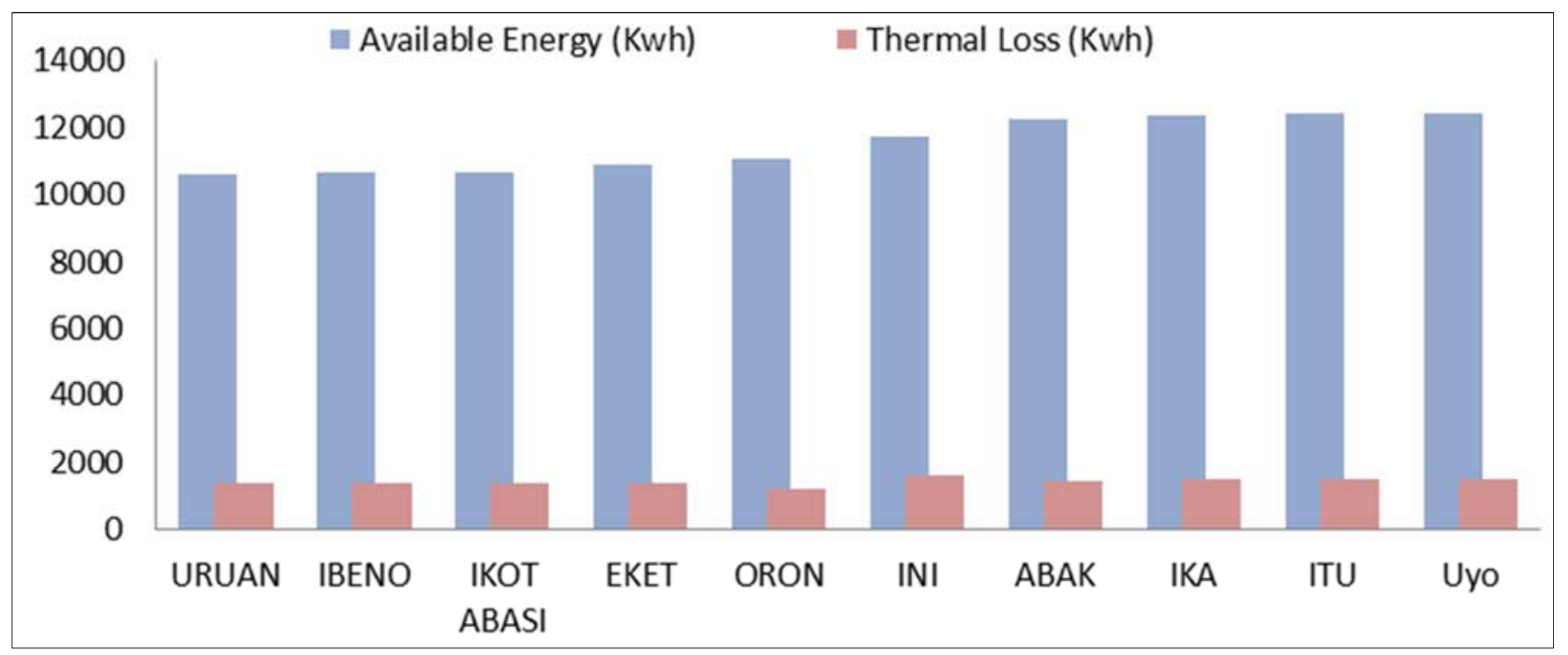

Figure 6. Available energy $(\mathrm{kW/h})$ and thermal loss $(\mathrm{kW} / \mathrm{h})$.

Table 9. Unit cost (Naira/kWh) and normalized available energy (\%).

\begin{tabular}{lll}
\hline LGAs & Yearly Unit Cost of Energy (Naira/kWh) & Normalised Available Energy in Percentage of the Largest Available Energy (\%) \\
\hline Uyo & 104 & 100 \\
Ika & 105 & 99.24 \\
Itu & 105 & 99.97 \\
Abak & 106 & 98.66 \\
Ini & 108 & 94.12 \\
Oron & 110 & 89.08 \\
Eket & 111 & 87.8 \\
IkotAbasi & 112 & 86.07 \\
Ibeno & 113 & 85.76 \\
Uruan & 114 & 85.26 \\
\hline
\end{tabular}

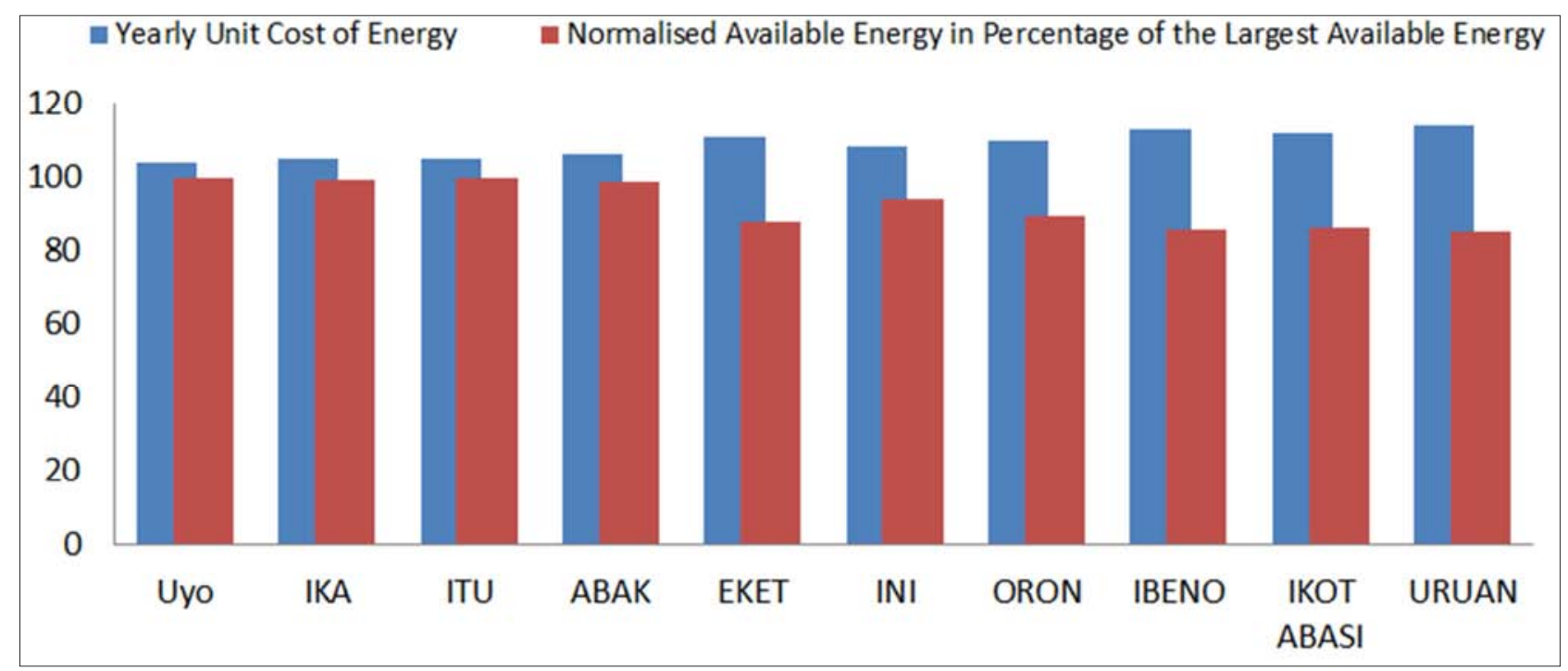

Figure 7. Unit cost (Naira/ $\mathrm{kWh}$ ) and normalised available energy (\%).

Conversely, in Table 9 and Figure 7, the peak value of unit cost of energy is $114 \mathrm{Naira} / \mathrm{kWh}$ and it occurred in Uruan whereas, the lowest value of unit cost of energy is 104 $\mathrm{Naira} / \mathrm{kWh}$ and it occurred in Uyo. A difference of 10 $\mathrm{Naira} / \mathrm{kWh}$ is observed between the highest and the lowest unit cost of energy among the selected LGAs in Akwa Ibom state.

\subsection{Model for the Unit Cost of Energy}

According to Table 8 and Figure 6, the peak value of solar energy generated by the PV array is $12422 \mathrm{kWh}$ and it occurred in Uyo whereas, the lowest value of solar energy generated by the PV array is $10591 \mathrm{kWh}$ and it occurred in Uruan. Conversely, in Table 9 and Figure 7, the peak value of 
unit cost of energy is $114 \mathrm{Naira} / \mathrm{kWh}$ and it occurred in Uruan whereas, the lowest value of unit cost of energy is 104 Naira/kWh and it occurred in Uyo. A difference of 10 $\mathrm{Naira} / \mathrm{kWh}$ is observed between the highest and the lowest unit cost of energy among the selected LGAs in Akwa Ibom

$$
\text { Yearly unit cost of energy }(\text { Naira/kWh })=\frac{73.23(\text { Available Energy per year in } k W h)}{(\text { Available Energy Per Year in kWh }-3736.271278)}
$$

$$
U(\text { Naira } / \text { kWh })=\frac{73.23(E)}{(E-3736.271278)}
$$

Where:

$\mathrm{U}$ is the unit cost of energy in Naira/kWh and $\mathrm{E}$ is the available energy in $\mathrm{kWh}$ per year

The unit cost model has a correlation value of $97.7 \%$ which shows very strong correlation between the available energy state.

Finally, from Table 10 and Figure 8, the trend line model (equation) relating the unit cost to the available energy per year is given as:

per year and the unit cost. It means that the available energy per year is accurately predicts about $97.7 \%$ of the unit cost of energy. The implication is that, the unit cost depends strongly on the energy that is available at the output of the PV array.

Table 10. Yearly unit cost of energy (Naira/kWh) versus available energy $(\mathrm{kWh})$.

\begin{tabular}{lll}
\hline LGAs & Available Energy (kWh) per year & Yearly Unit Cost of Energy (Naira/kWh) \\
\hline Uyo & 12422 & 104 \\
Itu & 12418 & 105 \\
Ika & 12328 & 105 \\
Abak & 12256 & 106 \\
Ini & 11692 & 108 \\
Oron & 11066 & 110 \\
Eket & 10906 & 111 \\
IkotAbasi & 10692 & 112 \\
Ibeno & 10653 & 113 \\
Uruan & 10591 & 114 \\
\hline
\end{tabular}

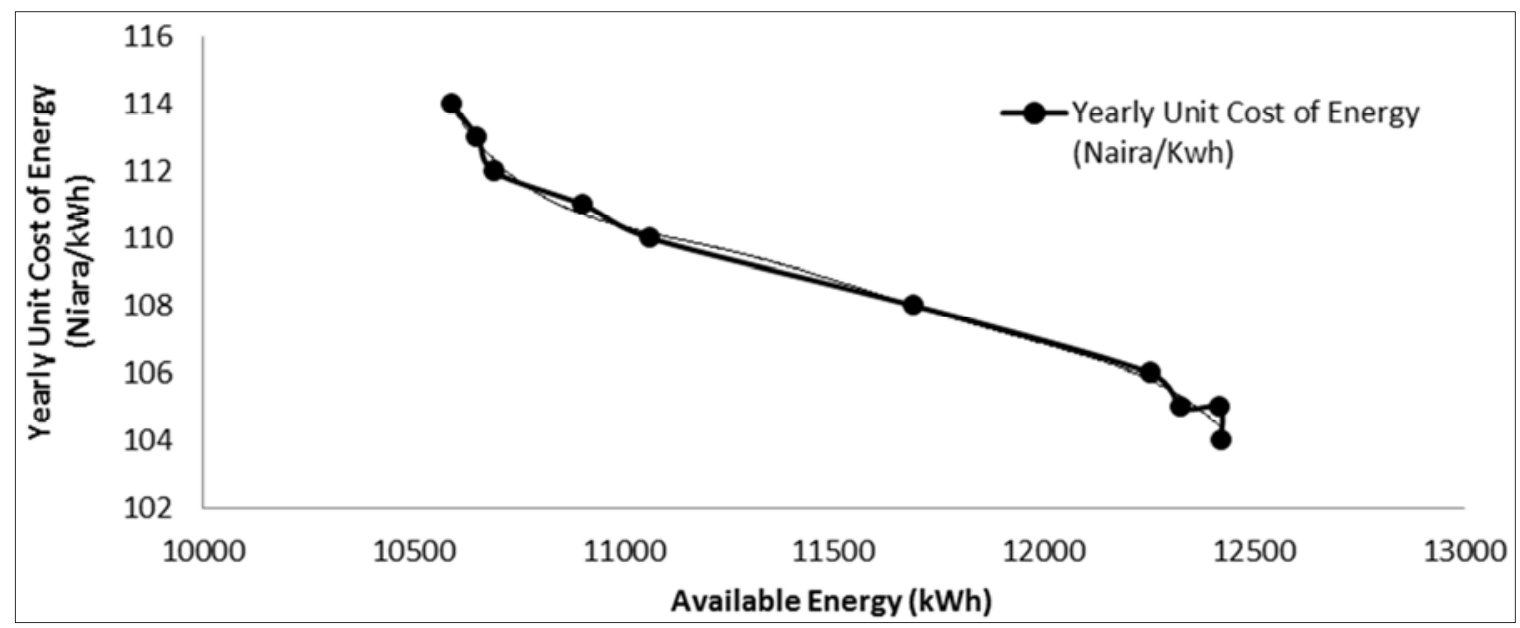

Figure 8. Yearly unit cost of energy (Naira/kWh) versus available energy $(\mathrm{kWh})$.

\section{Conclusion}

It can be concluded that Akwa Ibom state has the solar potential to generate electricity for both domestic and commercial purposes. Uyo LGA was ranked topmost. Uyo LGA has the highest yearly energy output of $12422 \mathrm{kWh}$ and lowest unit cost of energy of $104 \mathrm{Naira} / \mathrm{kWh}$. Uruan LGA was ranked lowest. Uruan LGA has the lowest yearly energy output of $10591 \mathrm{kWh}$ and highest unit cost of energy of 114 Naira/kWh. This shows that solar energy is spatiotemporal because it varies with time and location. It also shows that the amount of solar irradiance in a particular location determines the output of the PV module. From the results obtained in this paper it is clearly seen that cell temperature which is a function of ambient temperature and wind speed contributes to the thermal loss of the PV module. This affects the power output of the PV module and the unit cost of energy.

\section{References}

[1] Twidell, J., \& Weir, T. (2015). Renewable energy resources. Routledge. 
[2] Ellabban, O., Abu-Rub, H., \& Blaabjerg, F. (2014). Renewable energy resources: Current status, future prospects and their enabling technology. Renewable and Sustainable Energy Reviews, 39, 748-764.

[3] Ahuja, D., \& Tatsutani, M. (2009). Sustainable energy for developing countries. SAPI EN. S. Surveys and Perspectives Integrating Environment and Society, (2.1).

[4] Acar, C., \& Dincer, I. (2014). Comparative assessment of hydrogen production methods from renewable and non-renewable sources. International journal of hydrogen energy, 39 (1), 1-12.

[5] Kalogirou, S. A. (2013). Solar energy engineering: processes and systems. Academic Press.

[6] Bhusare, S. R. (2015). Renewable Energy: An Eco-Friendly Alternative?. Quest-The Journal of UGC-HRDC Nainital, 9 (2), 152-155.

[7] Letcher, T. M. (Ed.). (2008). Future energy: improved, sustainable and clean options for our planet. Elsevier.

[8] Luque, A., \& Hegedus, S. (Eds.). (2011). Handbook of photovoltaic science and engineering. John Wiley \& Sons.
[9] Perpinan, O., Lorenzo, E., \& Castro, M. A. (2007).On the calculation of energy produced by a PV grid-connected system. Progress in Photovoltaics: research and applications, 15 (3), 265-274.

[10] Nordahl, S. H. (2012). Design of Roof PV Installation in Oslo.

[11] Wiginton, L. K., Nguyen, H. T., and Pearce, J. M. (2010). Quantifying Rooftop Solar Photovoltaic Potential for Regional Renewable Energy Policy. Computers, Environment and Urban Systems, 34(4); 345-357.

[12] MacDonald, S. W. (2014). Quantifying Rooftop Solar Power for the City of Waterloo, Ontario. Unpublished Ph. D Thesis, Wilfrid Laurier University, Ontario, Canada.

[13] Ghosh, S. and Vale, R. (2006). The Potential for Solar Energy Use in a New Zealand Residential Neighbourhood: A Case Study Considering the Effect on $\mathrm{CO} 2$ emissions and the Possible Benefits of Changing Roof Form. Australasian Journal of Environmental Management, 13 (4): 216-225.

[14] Green, M., Watt, M. and Wenham S. (2009) Applied Photovoltaics. Sydney: The University of New South Wales. pp 593-610. 